\title{
Fejes Katalin
}

\section{A NőI SZÉPSÉG MEGMÉRETTETÉSE}

\author{
DOI 10.35402/kek.2021.2.4
}

\begin{abstract}
Absztrakt
A szépség lehet árucikk, társadalmi rang, hatalom. A szépség fogalma e tanulmányban nem esztétikai vagy filozófiai fogalomként szerepel, hanem a hétköznapok szintjén, a divatszalonok, a próbakisasszonyok, a szépségkirálynők és a leading ladyk világában. A szalonok által tervezett divatos ruhát a csinos, jó alakú manökenek tették vonzóvá, eladhatóvá. Velük szemben a társasági dámák nem a ruhát hangsúlyozták, hanem a ruhák által megteremtett, előnyös megjelenésükkel komoly társadalmi befolyásra tehettek szert. A szépség hatalma társadalmi és történeti kontextustól függ. Visszatetszővé válik egy olyan korszakban, amikor a szépségideált a társadalmi vagy faji kirekesztés politikájának szolgálatába állították.
\end{abstract}

\begin{abstract}
The beauty can be a product, a social rank, a power. The concept of beauty is not presented in this study as an aesthetic or philosophical concept, but at the level of the everyday, in the world of fashion salons, mannequins, beauty queens and leading ladies. The fashionable clothes designed by the salons were made for attractive and for sale by the pretty, mannequins with prefect shaped. In contrast to them, the social ladies did not emphasize the dress, but were able to gain serious social influence through the beneficial appearance created by the dresses. The power of beauty depends on social and historical context. It becomes attractive in an era when the ideal of beauty was put at the service of a policy of social or racial exclusion.
\end{abstract}

Vajon valóban igaz-e az az állítás, miszerint „szép az, ami érdek nélküli tetszik”? Létezik-e érdek nélküli tetszés? Hiszen már a görög istennők vetélkedésében sem az döntött, ki a legszebb, hanem az, melyikük kínált jobb alkut. Miután Héra, Pallasz Athéné és Aphrodité összevesztek azon az aranyalmán, amely a legszebbet illette, Zeusz úgy határozott, hogy a döntést Parisz hozza meg. Az istennők ígéretekkel próbálták megvesztegetni a királyfit, aki végül Aphrodité ajánlatát fogadta el és neki adta az almát.

Parisz a legszebb nő szerelmének ígéretéért „részrehajló” volt, mondhatni igazságtalanul, a saját érdekei szerint döntött. Vajon létezik-e olyan döntés, mely nem érdekeket szolgál? Márai Sándor az Újság oldalain, 1929-ben megjelent nyílt levele, melyet az első magyar szépségkirálynőnek, Simon Böskének ${ }^{2}$ írt, a választás döntését kérdőjelezte meg. Az író kendőzetlenül fogalmazta meg a véleményét, és nem leplezte, hogy nem ért egyet a győztes megválasztásával. Márai úgy vélte, a szépség megállapítása olyan szubjektív ítélet, amit nem lehet pontosan meghatározni. „Maga az én számomra például e pillanatban nem a legszebb magyar nő. Lehet, hogy két hónap múlva az lesz... reméljük, ugye? De addig határozottan nem Maga az én számomra a legszebb magyar nő, akiben a típus minden karaktere legeszményibben egyesül. A Szépség nem definiálható. Az emberi szépség meg egyáltalán nem definiálható. Ha a könyvekben utána olvas, azt fogja találni, hogy klasszikus értelemben szép az, ami érdek nélkül tetszik. Én megsúgom Magának abba a legszebb fülébe, hogy emberek között ez nem igaz. Emberek között az a szép, aki érdekkel tetszik. Mindig csak az a szép, aki érdekkel tetszik. Nekem érdekem, hogy tessék: az a szép." 3 Simon Böske lehet szép, de legszebb csak akkor, ha valakinek valamilyen érdeke füződik hozzá. Ha a szépség fogalmáról lehántjuk az esztétikai kritériumokat, és magasztos meghatározásokat, akkor nem marad más, mint az érdek által megjelölt szépség, vagyis

1 Márai 1929:8.

2 Simon Erzsébet 1924-ben, Keszthelyen a Korzó Szépének választották, majd 1925-ben a Balaton Tündére címet nyerte el, négy évvel később pedig, 1929-ben, ő lett Miss Hungaria, az első magyarországi szépségkirálynőválasztáson. Mint Magyarország legszebb lánya ő képviselte a párizsi Miss Európa versenyen az országot, ahonnan újabb trófeával tért haza. Utolsó megmérettetése Miss Európaként volt, Miss Americával szemben. Mivel a zsűri nem tudott dönteni a két versenyző szépsége között, ezért az 1929-ben megrendezett Miss Universe címért való versengés döntetlennel végződött.

3 Márai uo. 
az, amire Márai is utalt „Emberek között az a szép, aki érdekkel tetszik", ${ }^{4}$ és ezt Kant gondolataival lehet folytatni „Mert az ember nem nevezhet szépnek valamit, ha az csupán neki tetszik. Vonzó és kellemes sok minden lehet számára, ezzel nem is törődik senki; ha azonban valamit szépnek nyilvánít, akkor ezáltal ugyanazt a tetszést várja el másoktól is: nem pusztán a saját szempontjából, hanem mindenki nevében ítél, s ekkor a szépségről úgy beszél, mintha az a dolgoknak volna a tulajdonsága." ${ }^{5}$

\section{A szépség, mint árucikk}

A szépség, mint egyfajta varázserő jelent meg a modern fogyasztói társadalomban, amely elbűvölte, és megbabonázta a vevőket. Egy szép nő által reklámozott arckrém, vagy rúzs azt sugallta a vásárlóknak, hogy az adott termék megszerzésével ők maguk is csodálatosak, és vonzóak lesznek. A 20. század elejének divatszalonjai a próbakiasszonyokat tették meg a „vágy titokzatos tárgyává”, akik karcsú alakjukkal, etonfrizurájukkal egy új nőtípust testesítettek meg. „A manökeneket arra szánták, hogy a testüket használják közvetítő eszközként arra, hogy a fogyasztókban vágyat keltsenek, mind a divatszalonokban, mind a nyomtatott hirdetésekben." ${ }^{6}$ A szalon termeiben fel-alásétáló, ringó járású manökenek feladata volt elhitetni a vásárlókkal, hogy a bemutatott modelleket beszerezve ők maguk is elegánsak, csábítóak lesznek. Ám, egy jó üzleti érzékkel bíró kereskedő nemcsak a vásárlókat tudta ösztönözni, hanem a próbakisasszonyokat is. Hermann Gerson, a berlini ruhaipar egyik, zsidó származású megalapítója 1925-ben szervezte meg az első Divatkirálynő-választást, ahol az előkelő címért a próbakiasszonyok szálltak versenybe. Egy évvel később már magyar jelölt is indult a nemzetközivé szélesedett megmérettetésen.

1926 telén a Nőiruha-készítők Országos Szövetsége $(\mathrm{NOS} z)$ szervezésében került sor a Divatkirálynő-választásra, melynek résztvevőit, a divatszalonok próbakisasszonyait, a szalontulajdonosok választották ki a megjelenésük, és a mozgásuk alapján. A szakmai zsüri számára a döntő szempont az volt, hogyan tudja a modell bemutatni (ezáltal eladni) az adott ruhát. „Bennünket elsősorban azok a mozdulatok érdekelnek, amelyeket az üzletben

\footnotetext{
4 Márai uo.

5 Kant 2003:123.

6 Vasvári 2019:78.
}

végeznek a próbakisasszonyok. Nem a szépség a fontos..." - idézte a zsűri elnökének, Dán Leónak szavait a Pesti Napló munkatársa a versenyről készült beszámolójában. ${ }^{7}$

A báli szezon előtt megrendezett verseny a szalonoknak kedvező üzleti lehetőséget kínált, hogy felhívják magukra a figyelmet. A Divatkirálynő-választás nem másról szólt, mint a vevőkör szélesítéséről, melyet olyan vizuális látvánnyal értek el, ami vásárlásra biztatta a versenyen megjelent közönséget. A manöken szépsége, kecsessége mindössze egy eszköz - egy anyag - volt, amely a termék értékesítését szolgálta. „Dán elnök az eredmény kihirdetése után lelkesítő beszédet mond. Szóról-szóra ezt mondja: Az idei verseny anyaga jobb volt, mint az elmúlt évi, remélem, a jövő évi anyag még jobb lesz." ${ }^{8}$ A verseny, olyan, akár egy vásár, ahol terítékre kerül az anyag, legyen az emberi modell, vagy ruhamodell. A szépségipar „120as tempóval" száguldott végig a pesti utcákon és magával sodorta a női nemet. „Az egész világon a női szépségnek kivételes kultusza dühöng ma, amely kultusznak szakadatlan fokozása érdeke egy csomó ipar- és üzletágnak. A hölgyfodrásztól kezdve az udvari szállító ékszerészekig, a harisnyaügynöktől az automobil-gyárosig”. ${ }^{10}$

Az 1920-as évek végétől kezdve egymást érték a különféle szépségversenyek, mind a nemzetközi színtéren, mind Magyarországon. A szépségversenyek körül kialakult kultusz - köztük a Divatkirálynő-választás - nem az esztétikai értelemben vett tetszésen alapult, ami minden érdektől mentes, hanem a piaci jelenlétről szólt. A magazinok a példányszámot növelték, a szépségipar szereplői, valamint a divatszalonok a vevőkörüket. A Divatkirálynő-választás győztese valójában a szalonnak szerzett elismerést és magas haszonnal megtérülö befektetésnek bizonyult. A lapokban, magazinokban megjelenő beszámolókból az olvasók nyomon követhették a választások körüli eseményeket, a jelöltek társasági megjelenéseit, az európai versenyre utazó győztes külföldi szereplését. A Divatkirálynő-választás a szépség jegyében zajlott, csakhogy üzleti célt szolgált, ahol a szépség központi érték volt, de nem érdek nélküli. A szalonok a szépséget

\footnotetext{
7 Pesti Napló 1927. 12. 7.

8 Magyar Hirlap 1927. 11. 26.

9 120-as tempó (1937, rendező: Kardos László) címü vígjáték föszereplője Marianne (Muráti Lili), a modern lány, aki sportol, autót vezet, flörtöl, divatos a ruhája, sminkje, frizurája.
}

10 Nemzeti Újság 1926. 12. 9. 
nem mint „művészeti szép” fogalmat értelmezték, hanem stratégiai, azaz üzletszervező eszköznek tekintették. Ebben a piaci versenyben a szépség, mint anyagi érték jelent meg, mivel a választásokat figyelemmel kísérő - egyben fogyasztóként is megjelenő - közvéleményt erősen befolyásolhatta, hogy a győztes próbakisasszony mely szalonban dolgozott. ${ }^{11} \mathrm{~A}$ divatszalonok népszerüségéhez a korban szintén újdonságnak számító Szépségkirálynő-választás is hozzájárult. Az első versenyre 1929-ben került sor a Szinházi Élet képes hetilap szervezésében. Az olvasók naprakészen követhették a verseny eseményeit, amely ezáltal óriási reklámértékkel bírt. A beszámolók részben a győztes királynőről, másrészt a királynői „gardróbót” öszszeállító divatházakról szóltak. ${ }^{12}$

Ha megnézzük a korabeli magazinokat, láthatjuk, hogy a szalonoknak minden társasági esemény komoly reklámot jelentett, így számukra a szép vagy a legszebb nő nem a szépséget képviselte, hanem az általuk elkészített ruhamodell reprezentációját. „A mai divatkirálynőket a divatcégek és az illusztrált lapok emelik a frontra, de uralmunk legföljebb egy szezonig tart. (...) A megválasztott divatkirálynő az első napokban mámoros életet él. Meginterjúvolják, lefotografálják, lefestik, sőt filmre is kerül. A cég nagy reklámutazásokra küldi és ha szerencséje van, a műhelyből színpadra kerülhet, vagy, ha már a színház tagja, nagyobb szerepkörhöz juthat. De a legtöbb esetben az egész nagy gyönyörűség egy szezonig tart és az ünnepelt királynő visszakerül a műhelybe; tovább öltöget és ebédre megiszik a legközelebbi cukrászboltban egy csésze csokoládét."13

\section{A szépség, mint társadalmi rang}

A „királynők” neve hamar feledésbe merült, mivel évente újabb és újabb választásra került sor, illetve társadalmilag nem játszottak olyan fontos szerepet, mint a korszak társasági életének leading ladyjei. A születési és vagyoni arisztokrácia hölgyeinek, a felső középosztály nőtagjainak, és a közismert színésznőknek az élete, illetve stílusa

11 1926-ban a Holzer-divatház manökenje Csuppay Antónia nyerte meg a versenyt, 1927-ben a Rosengerné által vezetett szalon próbakisasszonya Kupfler Tini, míg 1928-ban Neumann Berta divatszalonjából Szügyi Mária.

12 Szinházi Élet 1929/4., 1932/7.

13 Magyar Jövö 1927. 10. 23. mindenki számára irigylésre méltó volt, amit a rangban alattuk állók igyekeztek utánozni. A magazinok olvasói napra készen követhették az ismert dámák toalettjeit, vásárlási szokásait, mert a divatrovatok részletesen beszámoltak a nagyobb társasági eseményeken (förangú esküvő, bál, színházi premier, lóverseny, stb.) részt vevő leading ladyk ruhájáról, és az azt elkészítő divatszalonról. „A Leading Lady elnevezés olyan megtiszteltetés, amit gazdagsággal, vagy társadalmi állással nem lehet megszerezni. Még a szépség és a tökéletes alak sem kvalifikál rá. A fönt felsoroltakon kívül első feltétele az abszolút ízlés, biztos kritériuma pedig az, hogy a Leading Lady nemcsak a férfiak, hanem a hölgyek elismerését is magára tudja vonni. Talán legpontosabban úgy határozhatnák meg, hogy Pesten az a Leading Lady, aki után a váci utcai korzón elismeréssel fordulnak meg a hölgyek". ${ }^{14}$ Ha a Szinházi Élet divatrovatának újságírója, Guthy Böske szerint értelmezzük a szépség fogalmát, akkor az nem más, mint a divatban való jártasság, mellyel a lapban rendszeresen szereplő leading ladyk rendelkeztek. Az arisztokrata és felső középosztálybeli egyén reprezentációjának egyik eszköze volt a divat, mivel egy adott ruha hűen szemléltette viselője társadalmi státuszát. „(...) lényeges egy rangnak az az érvényesítési módja, hogy azt a társadalmi szokás szerint e ranghoz illőnek tartott fellépéssel dokumentálják. A rang reprezentációja kérlelhetetlen kényszer."15 A leading ladyk egyedi tervezésű ruhákat hordtak, melyek tökéletesen illettek az egyéniségükhöz és az alakjukhoz. „A pesti divatszalonoknak még mindig legtöbbet forgalmazó vevői az arisztokrata dámák. Igaz, hogy ma már kevesebbet vesznek, mint békében, de viszont, mint a szalontulajdonosok mondják, a legideálisabb vevők, egyrészt mert nem alkusznak, másrészt mert mindig mindenki tudja, hogy mit akar és mi áll jól neki”. ${ }^{16} \mathrm{~A}$ toalettek - legyen szó otthoni vagy délutáni viseletről, estélyi- vagy sportruháról - megtervezésének feladata a divatszalonokra hárult. A vásárlók körében népszerü divatüzleteket a Film Szinház Irodalom kulturális hetilap az „Akik a pesti divatot irányítják" címü ${ }^{17}$ fotósorozatban mutatta be, ahol a képeken a korszak ismert közéleti

14 Szinházi Élet, 1936/45.

15 Elias 2005:81.

16 Függetlenség 1934. 12. 25.

17 A nő - Divat tarka-barka című divatrovat a Film Szinház Irodalom magazinban, szerkesztője Faragó Ilona (Faragó Baba néven publikált). 
nőszereplöi ${ }^{18}$ álltak modellt a belvárosi szalonok legfrissebb kreációiban.

Miközben a divatújságírók és a tudósítások az öltözködésen keresztül a szépség egyik megnyilvánulási formájáról beszéltek, azalatt a divatszalonok között kialakult egy rangsor, ahol a szépség, mint piaci mutató jelent meg. Egy szalon nagy befolyásra tehetett szert, ha a magazinokban a társasági élet ismert nőalakjai az általuk készített ruhákat viselték. A szépség elérésének egyik lehetőségét nyújtotta a divatos megjelenés, amellyel a módosabb középosztály rétege követhette - másolhatta - a felsőbb körök társasági hölgyeinek, valamint a korszak ünnepelt színésznőinek stílusát. „Az udvari arisztokrácia fó funkciója - a hatalmas központi uralkodó szempontjából - végtére is éppen az, hogy különbözzék (...) szabadon alakíthatja állandóan újjá a megkülönböztető társas viselkedést, a helyes magatartást, a jó ízlést, sarkában a feltörekvő polgári rétegekkel”. ${ }^{19}$

A kor ünnepelt színésznői gyakori szereplői voltak a magazinok és hetilapok divatrovatainak. Esetükben a szépség egyrészt a film által megteremtett érzéki szépséget jelentette - ez lehetett külső báj, belső kisugárzás -, másrészt viszont szépségük komoly piaci értékkel is bírt. A szépségnek ez a kettősége erősítette meg azt a szerepelvárást, amit a színésznők mutattak mind a vásznon, mind a magánéletükben. Sztereotípiákat testesítettek meg, melyre magát a sztárságukat is felépítették: a megközelíthetetlen tündérkirálynő Szeleczky Zita, a vibráló sportlady Muráti Lili, a harcias szűz Tolnay Klári, a királynői elegancia Simor Erzsi, a bájos naiva Turay Ida, a kacér Mezey Mária, vagy a lehengerlő végzet asszonya Karády Katalin. A magazinok cikkei csak ráerősítettek ezekre a mintákra, és olyan nőként írták le a színésznőket, melyet részben maguk, másrészt a körülöttük kialakított marketing is láttatni akart. „Rejtelmes történeteket suttognak róla, holott Kati a megtestesült őszinteség és még azt is elmondja magáról, ami esetleg ártalmára van (Karády Katalin). Az öntudatosság jellemzi színpadon és magánéletben egyaránt. Magának köszönhet mindent, keményen tört elöre és ezt nem mindig kesztyüs kézzel tette (Muráti Lili). Ebből a harmonikus, kiegyensúlyozott lényü asszonyból nyugalom áramlik át arra is, akinek a társaságában van (Simor

18 A gazdasági elitből Sorg Antalné, a politikai elitből báró Prónay Györgyné, a történelmi arisztokrácia tagjai közül a Cziráky Tonchette és Andrássy Ilona grófnők, gróf Festetics Miklósné Pallavicini Marisa, gróf Cziráky Miklósné Eszterházy Lilly, akik rendszeres „modelljei” voltak a divatrovatnak.

19 Elias 1987:771.
Erzsi). Féltő szeretettel őrködöm minden lépése fölött. Úgy érzem, hogy igen sokunknak húga, húgocskája (Turay Ida)". ${ }^{20}$

\section{A szépség, mint hatalom}

A színésznők filmen megjelenített érzéki szépsége nemcsak a partnerüket, hanem a nézőket is lefegyverezte. A végzett asszonyának Karády Katalint tekintették, de a megjelenésével, a viselkedésével, az életstílusával Szeleczky Zita, Muráti Lili, Mezey Mária, Simor Erzsi vagy Tasnádi Fekete Mária is divatot teremtett és diktált. ${ }^{21}$ Egy merészebb szabású ruha, bubifrizura, rúzs, a modern és divatos nő titka, ahogy ezt Turay Ida is gondolta az Uj rokon ${ }^{22}$ címü filmben. Málcsi (Turay Ida), hogy meghódítsa szíve választottját, levágatja copfjait, és bubifrizurát csináltat, kirúzsozza a száját és cigarettázik. A terve beválik, vőlegényjelöltje (Pethes Sándor), aki addig csak a kártyapartik miatt látogatta a „lányos házat”, most Málcsi kedvéért ül naphosszat a vidéki uradalom verandáján. Az addig sete-suta Málcsi ráérzett, hogyan használhatja fel a legősibb csábítóerőt, hogyan szerezhet hatalmat a férf felett.

A hangosfilm korszakának színésznői szerepeiket fokozatosan társadalmi szereppé konvertálták, és az általuk megtestesített szépségideál követendő lett a divatban, az életmódban, és az életszemléletben, amit különböző események ${ }^{23}$ népszerűsítésére használtak. A szépség eszközként segítette a célok elérését, amely a divatszalonok esetében a vevőkör bővítését, a politikai rendezvények esetében az aktuálpolitika propagálását jelentette. A „pozíciókszerepek-értékek" ${ }^{24}$ viszonya mellérendeltté vált, és mindössze - a weberi értelmezés alapján - csak az eszköz-, és a célérték különült el. „A célértékek jelölik ki a társadalom és az egyén számára a követendő cselekvéseket, melyek eredményeképpen a valóság irreverzibilisen átalakul. Az eszközértékek a cselekvések mikéntjét minősítik" ${ }^{25}$

\section{Szinházi Magazin 1940/52. \\ 21 Film Szinház Irodalom, 1942/27., 34., 1943/34. \\ 22 Új rokon (1934), rendezte: Gaál Béla.}

23 Sportrendezvények (1936-os berlini Olimpia); vásárok(BudapestiNemzetköziVásár, Őszi Lakberendezési és Háztartási Vásár), politikai rendezvények (I. és II. Magyar-Német Kívánsághangverseny 1944. április és 1944. május).

24 Csepeli 2001:143.

25 Csepeli 2001:233. 
A színésznők alakja köré épített mítosz és glamour elkendőzte - a rajongókkal esetleg feledtette - a valóságot. Az elegáns ruhákban, tökéletes frizurával és sminkben pózoló ideálok álomvilága vonzotta a rajongókat és a mozifilmek romantikus története tovább szőtte a vágyakat. „A tömegkultúrában a szépség újra a pompa és a bűvölet kifejezési formájává válik (...)"26 A mozi közönsége a magazinok és a bulvárlapok beszámolóiból jól ismerhette kedvenc sztárjainak mindennapi életét, amely sokkal nyitottabb volt,$^{27}$ mint a későbbi időszakokban. A Meseautó utasai magukkal ragadták a nézők kollektív képzeletét azt sugallva, hogy a szerelem minden társadalmi korlátot legyőz, a boldogság csak karnyújtásnyira van. A romantikus, varázslatos történetek a lehetőséget villantották fel, a divat-, és szépségkirálynők, illetve a mozisztárok megjelenésével pedig feltűnt egy új nőtípus. A modern nő karcsú volt, bubifrizurát hordott, festette a körmét és rúzsozta a száját, sportolt, emellett ismerte a legújabb divatot. „Ez a modern nő kissé kétlaki típus. Napközben kurta szoknyában dolgozik, vagy sportol. Este övig megmutatja a háta és dereka izmait. Szemérmetlenebb, de őszintébb, mint a régi generáció volt. Az ízlése annyira megváltozott, hogy lemosolyogja az úgynevezett hódító férfitípust. Sokkal inkább keres belső értékeket, mint a régi asszony. Ennélfogva - külső beállítása ellenére - sokkal kevésbé érzéki, mini a régi volt". ${ }^{28}$ - nyilatkozta a korszak ismert és közkedvelt írónője. A modern nő megjelenésében, viselkedésében teljesen ellentéte volt annak a nőképnek, amit korabeli társadalom elképzelt. A Divatkirálynőt, vagy a Szépségkirálynőt könnyủ életűnek és laza erkölcsủnek tartották, akik bájaikat tették közszemlére egy jobb élet reményében. Sokan azt gondolták, hogy a versenyen induló lányok túlléptek minden hagyományosnak tekintett elven, mind a külsőjükben (smink, hajviselet, öltözködés), mind a belső értékrendjükben. „És amily jók, kedvesek, csak a szeretetnek élők voltak az áruházak, a divatszalonok, a műtermek, a gyártelepek dolgos alkalmazottjai, vagy akár a tü, meg az olló mesternői, épp oly nagyok voltak az erények gyakorlásában (...). Akkor a házi erények voltak a tündöklő csillagok. Ma a fiatalságot az anyagiság uralja (...)" ${ }^{29}$

26 Balogh Gyöngyi - Király Jenő 2000:56.

27 Perczel Juliska Otthon rovata a Film Szinház Irodalom folyóiratban a bemutatott művész lakásának pontos címét is feltüntette a cikkeiben.

28 Esti Kurir 1934. 10. 13.

29 Budapesti Hirlap 1926. 12. 19.
A kispolgári környezetbe helyezett romantikus történetek a háború közeledésével elhalványultak, a modern nő képe elhomályosult. A történelmi Magyarország eszméje igyekezett kiszorítani a modern nőt és átszabni a divatot, és a filmipart. A divatszalonok magyaros stílusú ruhákba öltöztették a filmvászon ideáljait, amit összekapcsoltak a vidéki életmóddal, a falusi élettel, ahol a területeit elvesztett ország történelmi gyökereit vélte felfedezni. 1943ban a kultuszminiszter felkérte Zomboriné Barthus Irént, ${ }^{30}$ hogy kontrollálja a színésznők megjelenését. „Ismételten felmerült panasz, hogy az immár mindinkább tökéletesedő magyar filmekben szereplő művésznők modern öltözködését nem mindig kellő hozzáértéssel irányítják. „Erre való figyelemmel a jelenlegi állapot kiküszöbölése céljából megbízom Zomboriné Barthus Irén iparművésznőt, az iparművészeti iskola volt ruhatervezési oktatóját - aki több külföldi tanulmányút után a múltban és jelenleg is állandóan tanulmányozza a színpadi divatot és a különleges öltözködés szabályait -, hogy a jövőben készülő magyar filmekben szereplő művésznők számára készülő modern ruhatervek felülbírálására álljon a gyártó cégek rendelkezésére, amelyek igazolni tartoznak, hogy Zomboriné Barthus Irén a filmen szereplő művésznők ruháit kifogástalannak találta”. ${ }^{31}$

\section{Konklúzió}

Ha a szépség fogalmát a divat oldaláról közelítjük meg, láthatjuk, hogyan válhat árucikké, vagy adhat rangot és befolyást. A divatdiktátorok nemcsak külső megjelenésükkel tudtak hatni követőikre, rajongóikra, hanem hatással voltak életvitelükre, és gondolkodásukra is. A fent vizsgált esetben a szépség a hatalom eszközévé vált, legyen szó gazdasági térnyerésről, például a piacvezető divatszalonok esetében, vagy egyéni befolyásról, mint a szépségideálok, például a színésznők esetében, illetve akkor, amikor politikai hatalom is szolgálatába állította.

Létezik-e önmagában vett szépség? Létezik-e szépség anélkül, hogy ne fonódna össze a hatalommal és ne szolgáljon gazdasági és/vagy politikai

30 Zomboriné Barthus Irén a két világháború közötti magyar divattervezés egyik neves szereplője. Az Országos Iparművészeti Főiskola ruhatervezési szakoktatója, illetve a Magyar Filmiroda Ruhatervezési Bizottságának elnöke volt.

31 Beregszász Kárpáti Híradó 1943. 1. 24. 
érdekeket? Ha visszakanyarodunk a kanti filozófiához és Márai soraihoz, azt kell látnunk, hogy abban a pillanatban, amikor a szépség ideáljáról beszélünk, a szép már nem „érdek nélküli”. Az ideált az ízlés teremti meg, a szépségideált a divatszakma, a sztárideált a filmszakma, a korszak ideált a hatalom. „Szépség mindig lesz. A szépségnek van jövője. Hogy a közelebbi jövőnek szépsége is? Ez persze...” ${ }^{32}$ 1934ben az Est Hármaskönyvében írta ezeket a sorokat Lakatos Lászlón ${ }^{33}$ író, újságíró, amikor a Harmadik Birodalomban már körvonalazódni kezdett a faji alapokra épülő szépségeszmény.

\section{Felhasznált irodalom}

A modern leány - Erdős Reneé nyilatkozata. (1934. 10. 13.) Esti Kurír, 4.

A szerkesztő 12 színésznőről. (1940) Szinházi Magazin, 52:12-15.

Balogh Gyöngyi - Király Jenő 2000 „Csak egy nap a világ...". Magyar Filmintézet, Budapest.

Carneval hercege megérkezett $s$ egymást érik az estélyek és bálok. (1929) Szinházi Élet, 4:83.

Csepeli György 2001 Szociálpszichológia. Osiris Kiadó, Budapest.

Elias, Norbert 1987 A civilizáció folyamata. Gondolat, Budapest.

Elias, Norbert 2005 Az udvari társadalom. A királyság és az udvari arisztokrácia szociológiai jellemzöinek vizsgálata. Napvilág Kiadó, Budapest.

Endrődi Béla: Aranytrombita. (1926. 12. 9.) Nemzeti Újság, 5.

Guthy Böske: Akik után mindenki megfordul. (1936) Szinházi Élet, 45:72-76.

Guthy Böske: Elegáns pesti asszonyok. (1934. 12. 25.) Függetlenség, 33.

Hamlet és a Divatkirálynő. (1926. 12. 19.) Budapesti Hirlap, 4-5.

Hogyan születnek a divatkirálynők? (1927. 10. 23.) Magyar Jövö, 7.

32 Lakatos 1934:347.

33 Lakatos László (1881-1944) 1903-tól a Pesti Hírlap, a Magyar Nemzet, a Pesti Napló munkatársa, majd a Világ szerkesztője. Az I. világháború után az Est-lapok munkatársa, a Magyarország szerkesztője. A II. világháború kitörése után, származása miatt Franciaországba emigrált. A Gestapo üldözése elől az öngyilkosságba menekült. (Forrás: Wikipedia) (d.m.): Izgalmas verseny után megválasztották a budapesti mannequinek királynőjét. (1927. 11. 26.) Magyar Hirlap, 5

Kant, Immanuel 2003 Az itélöerö kritikája. Osiris Kiadó, Budapest.

Lakatos László 1934 A szépség jövője. In Dernői Kocsis László - Mihályfi Ernő - Szabó Lőrinc szerk. Az Est hármaskönyve. A Szépség Könyve. Est Lapkiadó Rt., Budapest.

Márai Sándor: Szépségverseny. (1929. 1. 8.) Újság, 8.

Milyen lesz a „Muráti-divat”? (1942) Film Szinház Irodalom, 34.

Mit visel Miss Magyarország Párizsba és Nizzába? (1932) Szinházi Élet, 7:82-84.

Nem a szépség a fontos, hanem a mozdulat... (1927. 12. 7.) Pesti Napló, 10.

Nyári divat-vizit Simor Erzsinél. (1942) Film Szinház Irodalom, 27.

(Magy. Tud.) Rendeletet adtak ki a filmszínésznők öltözködésének ellenőrzéséről. (1943. 1. 24.) Beregszász Kárpáti Hiradó, 4.

Színésznők a divat nélküli divatról. (1942) Film Szinház Irodalom, 34.

Vasvári, Louise O. 2019 Simon Böske, Miss Hungária és Miss Európa, 1929: nemi szerepek, faj és nemzeti identitás a két világháború közötti Magyarországon. In Kőbányai János főszerk. Múlt és Jövö, 2:78. 